\title{
2. A two-nation Asian
}

\section{phenomenological study Roles and purposes of graduate journalism education through the lens of global journalism}

\begin{abstract}
This phenomenological study sought to describe the essence of the roles and purposes of graduate journalism education through the eyes of 16 Asian students from three graduate journalism schools in Japan and the Philippines. This article is anchored in the theory of reflective practice. Responses of students produced a Bridge of Traits of Graduate Journalism Education that illustrates these roles and purposes of graduate studies. This Bridge of Traits also entered into the theory-and-practice discussions, not to mention that this bridge represents respondents' efforts to connect their personal, academic and professional milieus and aspirations as journalists. Making these connections is done within the realm of journalism's theory-practice continuum, which, as respondents surprisingly articulated, is important, complementary and applicable. Respondents' views offer hope that university-based journalism programmes can run viable graduate journalism programmes implementing several elements in pedagogy and substance that espouse a spirit of critical reflective practice in journalists. They aspire to new perspectives and approaches in the teaching, study and practice of journalism.
\end{abstract}

Keywords: graduate journalism education, journalism school, phenomenology, reflective practice, theory-and-practice in journalism, Philippines, Japan

JEREMAIAH M. OPINIANO

University of Santo Tomas, Philippines

\section{Introduction}

EBATES on journalism education persist, especially if the subject matter is based on the 'theory-versus-practice' issue (Josephi, 2015). Journalism is said to be an industry skill that professional journalists can teach students and many journalism schools are then being encouraged to adjust their curricula according to the required skills of the industry. However, journalism schools housed in universities are centres of research and knowledge. Not only 
should journalism teachers impart industry-required skills, they also must do research and wear an academic's hat in analysing issues and trends in the news media (Barkho, 2013). This theory-versus-practice debate not only has reached areas such as pedagogy but even the issue of what works are (un)recognised as 'journalistic' and as 'academic' by both parties (Murthy, 2015; Woolley, 2015; Tanner, 2015; Chua, 2015; Anuar, 2015; Duffy, 2015; Kemper, 2015; Mason, 2015). Even the recognition of journalism as a field of study (i.e. journalism studies), while said to be still 'young' is being questioned (Franklin \& Mensing, 2011).

This debate takes into context how countries train students in journalism. Some countries, such as the United States, have accommodated journalism degree programmes in universities. In other countries, professional institutes and news organisations, or companies, train journalists and grant degrees (Josephi 2015) in the absence of educational institutions offering journalism degree programmes. Another context here is how a country's news media operates, as well as the levels of freedom of expression in the country.

Many journalism programmes in universities worldwide have followed Western models. However, some of these models may not work (e.g. role of journalism in a democracy) given the varying status of the news media, freedom of expression and of the press in different countries. These internal and external developments impact on how journalism education is delivered (Josephi, 2015; Opiniano et. al, 2015). So continues the never-ending calls to re-assess, re-invent and re-configure journalism education (e.g. Mensing, 2011; Webb, 2015). Now, media platforms have forced news organisations to connect stories from different parts of the world to a global audience. Journalism schools living in isolation will be disconnected from global trends in journalism education and even to other journalism educators and scholars who can help each other out. News media systems also differ across regions and countries, providing an interesting model of how the professional model of journalism may be taught given varied socio-political milieus (Josephi, 2007).

These developments have led to the rising globalisation of journalism education. Some countries now offer graduate programmes in journalism that are on top of the bachelor's programmes that have defined the 'explosion' of journalism education worldwide (Self, 2015; Josephi, 2015). The theory-practice debates surrounding journalism education have now reached graduate levels. The offering of master's or doctorate degrees in journalism is a young phenomenon, and this may be new terrain for both universities/professional institutes and for the field called Journalism Studies. Meanwhile, aspiring and current journalists may be looking at graduate education as a passageway to discover - and to know further - the world of journalism. But why do these journalists take up graduate studies in journalism? What role and purpose does this graduate programme experience have on the student? What do these graduate students think of the 
theory-versus-practice debates in journalism education? With journalism as a 'profession' and as a 'discipline' still finding its place in a university setting, studies on graduate journalism education remain scarce.

This phenomenological article seeks to find out from Japanese and Filipino graduate journalism students the roles and purposes of journalism graduate studies relating to them. The article will contribute to the few studies on graduate journalism education (Carpenter, 2008). But this study offers not just non-Western views about journalism education; it will also be a modest attempt to see how graduate students' views relate to similarly-situated conditions (be it the graduate students or the journalism schools) in developing and developed countries, in the spirit of global journalism education.

\section{Theoretical background}

\section{Review of related literature and studies}

\section{a. Journalism education and the theory-versus-practice debates}

Journalism education has come a long way since a first degree programme in the United States was offered in 1869 (Josephi, 2015). The offering of journalism programmes past and present is owed to the growth of media outfits and the resulting demand for trained professionals in individual countries; the dramatic increase in reader/viewer/listenership (Josephi, 2015); and more recently technology and the internet.

The approach to journalism education has also evolved. Journalism education has for a long time been training future journalists of a country's news media industry with curricula aligned to industry needs. However, since many of these journalism programmes are housed in universities, the journalism programme must now consider operating itself under the usual three-fold mission of a university: teaching, research and service.

This is where the theory-versus-practice debates escalate, leading to 'disdain', 'misunderstanding' or 'miscommunication' between and among professional journalists, journalism educators and journalism scholars (see Zelizer, 2004). Meanwhile, Journalism Studies emerged as a field of study. Scholarly journals on journalism became the outlets for scholars to further the theory-versus-practice debates. Even if Barbie Zelizer's (2004) book Taking Journalism Seriously had attempted to bring journalists, journalism educators and journalism scholars to the table and let them see mutual benefits from each other's views, recent works provide evidence of continued debates (Anuar, 2015; Barkho, 2013; Clarke, 2010; Lugo-Ocando, 2015; Marsh, 2015; Ray, 2014).

One scholar who has put forward an all-encompassing vision for journalism education is G. Stuart Adam. Journalism's daily grind and the university's intellectualism must be both taught, Adam wrote. Students' reporting, writing and research skills may need to be complemented by disciplinal and specialisa- 
tion subjects (e.g. history, law, ethics, economics, political science, sociology, language studies) so that written outputs are sprinkled with substance coming from the influences of these disciplines (Adam, 2006) ${ }^{1}$.

Another established journalism scholar, Stephen Reese, affirms Adam's insights in the context that academia and the industry are partners - and journalism's 'intellectual ethos' can be nourished by this academe-industry collaboration. In Reese's own words (1999, p. 90):

Partnerships can be productive relationships and (can be) necessary in tackling complex problems, and joint ventures a common fixture in corporate life. It must be clear, however, what one is getting out of the relationship. Academia may properly be a partner, but it should not become a mere client of the corporate world or the professions. Educators must think through what they are about, especially in journalism with so many constituencies. For all of its faults, the university provides a valuable source of leadership for society and for journalism that cannot be replicated elsewhere...

Adam and Reese, as well as other journalism education scholars like Donica Mensing (Mensing, 2011; Franklin \& Mensing, 2011), put forward these insights so as to ease the theory-and-practice 'tension'. This debate puts people 'between a rock and a hard place', as the late American journalism educator James Carey expressed at the 1972 conference of the Association of Educators in Journalism and Mass Communication (AEJMC) in the US.

\section{b. Graduate journalism education}

Graduate education for journalists serves to 'retrain journalists' who entered the industry and to help undergraduates seek additional specialisation and skills. ${ }^{2}$ Folkerts (2014) observes these programmes 'had for many years been given scant attention by industry leaders, academics or associations that formed around journalism education' (p. 287). Yet some of the famous journalism schools are graduate-level programmes, such as Columbia University's in the US.

Basically, a 'higher educational level' for the journalist can be a 'very formative type of education' for journalists (Schultz, 2002, p. 225) as they analyse the works and outputs of media content, the professional conduct of journalists, and other journalism-related phenomena. Journalism degree programmes at the master's level can either be professional degrees (their capstone being an investigative report, a narrative journalism story, and other related outputs) or academic degrees (with a master's thesis as the culminating requirement). This, even as Soloski (1994, p. 6) feared 'professional education' that leads to specialisation will see students being taught with skills 'that limit, rather than expand, their opportunities'.

Then the theory-versus-practice debate ensues at the graduate level. And 
James Carey's 1972 plea was resurrected by three former deans of top American journalism schools (in Educating Journalists: A New Plea for the University Tradition). The Columbia report focused almost entirely on American journalism education, but there is recognition of the theory-practice tension in journalism programmes worldwide (there is 'no obvious solution to the tension between ... university and newsroom cultures' [Folkerts, Hamilton \& Lemann, 2013, p. 59]). But basically, Educating Journalists affirmed the treatises of Adam (1989) and Reese (1999): graduate journalism education in a university setting is important - and both theory and practice can benefit:

...(Graduate journalism education) is the place where the fundamental questions that have dogged our field from the very beginning are most likely to be resolved. That is not only because of the prestige of graduate education, but also because graduate programs have to offer a much more complete education: they do not operate under the traditional undergraduate division of skills education inside the journalism program and most of the rest of a student's education elsewhere in a university. Graduate programs claim to turn an educated person into a professional journalist.

...Journalists perform a socially-essential and intellectually-challenging role that ought to merit inclusion in the pantheon of professions. Businesses need to establish themselves only in the marketplace. Professions must also establish themselves in universities, in professional schools of their own that are deeply involved in the larger academic enterprise. That is why... it is especially important that journalism schools take the fullest possible advantage of our university location. If they can do that, all of journalism will benefit. (Folkerts, Hamilton \& Lemann, 2013, pp. 59, 64)

Under such a vision, there can be hope that the divides between theory and practice 'must be regarded as one and the same time as vast, but also as ultimately bridgeable'.

\section{c. Studies on graduate journalism education and its students}

Studies on graduate journalism education are a mix of scholarly commentaries and empirical research. Most of these studies are West-centric, pointing to the scarcity of related studies from other mediascapes. Students, their published research works and the journalism schools themselves have been these studies' units of analysis.

Graduate education is a welcome opportunity for students, akin to how undergraduates enjoy journalism education. Saalberg's (1970) survey of 43 master's degree-granting journalism schools showed that the degree programmes are welcome opportunities for these students to learn basic and some advanced skills in journalism that they lack.

Undergraduate and graduate education/degrees may or may not have influenced 
their views on the roles of journalists. O'Boyle and Knowlton (2015) compared 'postgraduate students' from Dublin, Ireland and Amman, Jordan on their entry into journalism through graduate education. Findings reveal differences in how students view themselves; their roles (e.g. activist, neutral) are impacted on by the culture of their countries' journalism. Hanna and Sanders (2007) compared undergraduate and graduate-level British journalism students' views and news media roles. Results of their study (sample of arriving students: $N=291$; sample of students who graduated/completed: $\mathrm{N}=208$ ) showed little evidence of students' attitudinal change during the time that they were students. The results may be attributed to personal and family backgrounds, and to students' exposure to British news media culture.

Schultz (2002) attempted to determine the characteristics of journalists who went to graduate school versus journalists who are college graduates only. Based on two US surveys (1992 and 1996), results showed few differences in those students' perceived influences in education, journalistic role concepts and audience perceptions. But journalists with a graduate degree, Schultz found, were more likely to work for larger news organisations and to support an interpretative role by journalists.

Graduate education in journalism, not surprisingly, had pushed students to do research apart from journalistic writing. Christ and Broyle (2007) did a benchmark study of graduate education at American universities' communication and journalism programs $(\mathrm{N}=40)$. The graduate programs surveyed appear to have prepared students for research and teaching but not in community service. Carpenter (2008), for her part, looked at how graduate students as authors or coauthors ( $\mathrm{N}=723$ students writing 543 articles from ten journals over a nine-year period) of scholarly journal articles got published in the top journals.

Graduate education can also influence students' ethical practices. Valdez (2013) studied the motivations of Asian students in pursuing a Philippine university's master's program $(\mathrm{N}=63)$. Under the guidance of a professional competence model as the author's framework, it was found that there is high knowledge gain in ethical decision-making by students. Ethics had the greatest improvement in students' knowledge acquisition from the graduate journalism programme, and the ethics course the most useful course to students' journalistic work.

These previous studies had looked at the schools' and graduate students' profiles, their views and attitudes on the roles of journalists, and their motivations to pursue graduate education in journalism. Only one study employed a qualitative design (O'Boyle \& Knowlton, 2015), although much can still be researched on. One area that remains to be studied is the role and purpose of students' pursuit of graduate education in journalism. Are these students realising how a theorypractice divide may be helpful to their education and, for some, their eventual pursuit of a career in journalism? 


\section{Theoretical framework}

Susan Greenberg (2007) first wrote about using the Theory of Reflective Practice by Donald Schön (1983) as a solution to the theory-practice divide in journalism education. Schön's theory of reflective practice is being used as a theoretical anchorage for this article.

Reflective practice is said to be a process of learning through and from experience towards gaining new insights of self and/or practice (also in Finlay, 2008). Reflective practice is said to involve examining assumptions of everyday practice; it also makes individual practitioners self-aware and critically evaluative of their own responses to practice situations. The point of reflective practice is that the student/practitioner 'recapture(s) practice experiences and (mulls these) over carefully in order to gain new understandings and so improve future practice' (Finlay, 2008). A host of models have modified this theory of reflective practice, said to be an outcome of the Experiential Learning Theory (ELT) of David Kolb (1984).

A related model that stems from Schön's reflective practice and Kolb's ELT is Graham Gibbs' Reflective Cycle (in Finlay, 2008) (Figure 1). This model proposes the enrichment of theory and practice on each other 'in a never-ending cycle' (i.e. iterative). Learners here make six steps: description, feelings, evaluation, analysis, conclusion and action plan. Gibbs' model (Finlay, 2008) carried the following aims: a) Challenge one's assumptions; b) Explore different/new ideas and approaches towards doing or thinking about things; c) Promote self-improvement given the identification of strengths and weaknesses and taking action to address things; and d) Link practice and theory by combining, doing or observing with thinking or applying knowledge.

Journalism, being an industry-oriented field, does immerse its practitioners to learn the ropes of the profession. Given the pace of journalism work, there may be little room for journalists to discern themselves, their duties, their personal aspirations and their dispositions about the roles of journalists before the public.

\section{Figure 1: Graham Gibbs' Reflective Cycle}

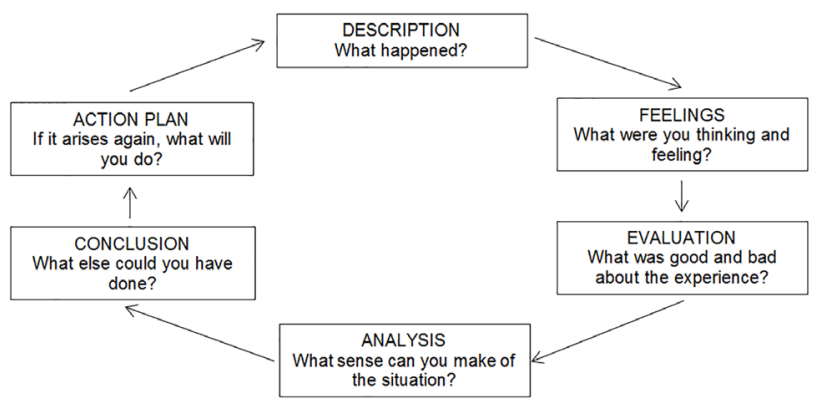

Source: Finlay, 2008 
Graduate education by journalists may provide that venue of reflective practice. In a sense, the vision of Folkerts, Hamilton and Lemann (2013) for graduate journalism education thus fits into the theory of reflective practice (Kolb) and the reflective cycle model (Gibbs).

\section{Methods}

To describe the essence (lebenswelt) of the roles and purposes of graduate journalism education unto students, descriptive phenomenology was used. Phenomenology (Husserl, 1970, cited in Wojnar \& Swanson, 2007, p. 173) is the 'science of the essence of consciousness formed on defining the concept of intentionality and the meaning of lived experience from the first person point of view'. To be characterised here are the individual and collective experiences of graduate journalism students $(\mathrm{N}=16)$ from one Japanese and two Philippine graduate journalism schools.

Qualitative research enables to fully describe a phenomenon in the perspectives of both the researcher and the reader. For people to understand better, 'they should be provided with information in the form which they usually experience'. In so doing, the depth and breadth of the qualitative data this research gathered will remain to provide information and insights on the phenomenon being studied. This approach for qualitative research thus yields findings that harmonise with readers' experiences (Lincoln \& Guba, 1985).

\section{Study site and selection}

This study was located at three graduate journalism schools in Japan (Waseda University) and the Philippines (Asian Institute of Journalism and Communication [AIJC]), and Ateneo de Manila University and its Asian Center for Journalism [ACFJ]) (Table 1). Having subjects that are from developed and developing countries finds similarity to what O'Boyle and Knowlton (2015) did.

\section{a. Profile of the journalism schools}

Waseda University offered Japan's first master's degree programme in journalism. This was to address the need for a 'professional journalism school in Japan' (WU01, interview). It is the newspaper companies that train the journalists, with special emphasis on the on-the-job training. Waseda started off with certificate programmes in science and technology journalism, environmental journalism, medical journalism and political journalism (WU02).

Ateneo de Manila University's Asian Center for Journalism (ACFJ) was founded under the School of Social Sciences. With financial support from the Konrad Adenauer Foundation since the centre began in 2000, journalists across the continent — especially from South and Southeast Asia — are the ACFJ's target and its curriculum rooted in the Asian tradition (AdMU01 and AdMU02, interviews). The Asian Institute of Journalism and Communication (AIJC) is a professional 


\begin{tabular}{|l|c|c|c|}
\hline \multicolumn{4}{|c|}{ Table 1: Brief profile of the graduate journalism schools studied } \\
\hline \multirow{2}{*}{$\begin{array}{l}\text { Student diversity (current) } \\
\text { • All locals }\end{array}$} & AIJC & Waseda & Ateneo \\
\cline { 2 - 4 } & & & \\
\cline { 2 - 4 }$\quad$ International & yes & - & - \\
\hline Number of units & 39 & Yes & Yes \\
\hline Scholarship arrangements & None & 39 & 42 \\
\hline Year of first offering & 1980 & 2008 & Yes \\
\hline
\end{tabular}

institute that was formed as a graduate school of journalism in 1980, working then with the Journal Group of Publications in Manila to offer a master's degree in journalism in the 1980s. AIJC stressed development journalism which helped in the transformation of the center as an educational institution-cum-consultancy group that does commissioned research on communication and journalism issues in the Philippines and other parts of the world (AIJC website; AIJC01, interview).

\section{b. Profile of the respondents}

This study interviewed 11 graduate students from Japan and five from the Philippines, as well as the programme heads and some colleague faculty of the master's programmes in journalism (Table 2). Most of the respondents are new entrants in journalism education, especially given that journalism in Japan is taught as a master's degree programme. While the Japanese students were currently taking their internship at the time of the interview, three of the five Filipino graduate students have ongoing news media experience. Having a limited number of respondents from the Philippines is admittedly a limitation of this research since Filipino working journalists are cornered by their daily reporting duties and have little or no time to be interviewed.

Homogenous sampling was employed here since participants are all graduate students who may have almost similar experiences. But maximum variation sampling was also considered for this paper since participants have diverging forms of experiences as seen from their backgrounds prior to and during their entry into graduate school.

\section{Procedure and research instrumentation}

The Waseda and AIJC students were interviewed in batches of three. The Ateneo de Manila students were interviewed individually given the difficulty of getting an agreed schedule for students who are currently full-time journalists. ${ }^{3}$ Interviews conducted were free-flowing and their answers were transcribed with their consent. Statements in Filipino were carefully translated, interpreted and checked in order to remain faithful to the original meaning of their answers.

Respondents' sharings and musings revolved around the key questions for this 


\section{Table 2: Profiles of interviewees}

\begin{tabular}{|c|c|c|}
\hline A. Graduate journalism students & Male & Female \\
\hline \multicolumn{3}{|l|}{ Age brackets } \\
\hline \multirow{5}{*}{$\begin{array}{ll}\cdot & 21-25 \\
. & 26-30 \\
. & 31-40 \\
\cdot & 41-50 \\
. & 51 \text { above }\end{array}$} & 4 & 8 \\
\hline & 1 & - \\
\hline & 1 & - \\
\hline & 1 & - \\
\hline & - & 1 \\
\hline \multicolumn{3}{|l|}{$\begin{array}{l}\text { With professional journalistic experience prior } \\
\text { to MA study (internship excluded) }\end{array}$} \\
\hline \multirow{2}{*}{$\begin{array}{ll}\text { - } & \text { Yes } \\
\text { - } & \text { No }\end{array}$} & 2 & 0 \\
\hline & 5 & 9 \\
\hline \multicolumn{3}{|l|}{ Undergraduate training } \\
\hline \multirow{2}{*}{$\begin{array}{ll}\text { - Journalism or communication-related } \\
\text { - } \quad \text { Other degrees }\end{array}$} & 3 & 1 \\
\hline & 4 & 8 \\
\hline \multicolumn{3}{|l|}{ Financial support for MA study } \\
\hline \multirow{2}{*}{$\begin{array}{ll}\text { - } & \text { Self-paying } \\
\text { - } & \text { On scholarship }\end{array}$} & 5 & 8 \\
\hline & 2 & 1 \\
\hline \multicolumn{3}{|l|}{ Nationalities } \\
\hline \multirow{5}{*}{$\begin{array}{ll}\text { - } & \text { Japanese } \\
\text { - } & \text { Chinese } \\
\text { - } & \text { Taiwanese } \\
\text { - } & \text { Singaporean } \\
\text { - } & \text { Filipino }\end{array}$} & 2 & 5 \\
\hline & - & 2 \\
\hline & - & 1 \\
\hline & - & 1 \\
\hline & 3 & 2 \\
\hline \multicolumn{3}{|l|}{$\begin{array}{l}\text { B. Program heads of graduate journalism } \\
\text { program }\end{array}$} \\
\hline \multirow{3}{*}{$\begin{array}{ll} & \text { Gender } \\
\text { - } & \text { Holder of PhD } \\
\text { - } & \text { With professional journalistic } \\
& \text { experience (news organisation) } \\
\end{array}$} & 2 & 3 \\
\hline & 1 & 3 \\
\hline & 1 & - \\
\hline
\end{tabular}

research: a) Personal background prior to entering into graduate school; b) Purposes for taking up graduate journalism education; c) Views on the theory-and-practice debate that these students immerse themselves in while studying and while doing media work; and d) Roles of graduate education for the said student.

Mode of analysis and ethical considerations

To capture the essence of the phenomenon, Colaizzi's seven-step method of phe- 
nomenological data analysis was done (1978). The data were read and re-read as selected verbalisations from the 16 respondents helped collectively describe the commonalities of respondents' views and experiences. Condensed meanings of the significant statements led to the categorisation of codes, sub-themes and major themes.

Cool and warm analyses, facilitated by the use of a dendrogram, were done in order to capture the central meaning of respondents' experiences. Themes that emerged from their answers were labeled as truthfully and accurately, with each major theme assigned a metaphor. In turn, an outcome space was developed as the result of this phenomenological research (in Larsson and Holmström, 2009).

Member checking and critical friend techniques were done to validate data, especially when assessing their trustworthiness. The researcher also assured respondents that their identities would be kept confidential given the consent they gave.

\section{Findings}

Five themes emerged from the articulations of 16 Asian journalism students' meanings of the role and purposes of graduate journalism education. Looking at how the themes emerged, respondents took cognisance of not just their personal realisations while studying but also their understanding of the theory-andpractice relationship in graduate journalism education.

An overall look of respondents' answers, and the contexts where they are situated, can be likened to a truss bridge. A truss 'is a triangulated framework of elements that act primarily in tension and compression' (Tata Steel Construction, n.d.). This type of bridge is a common design for a bridge in many parts of the world. Like any type of bridge, the structure deals with tension (a force that pulls materials apart) and compression (a force that squashes materials together). Vehicles of various loads passing through truss bridges provide those tension and compression forces, which is why truss bridges are considered 'expensive to fabricate' (Tata Steel Construction, n.d.).

Having said that, graduate journalism education can be likened to a truss bridge wherein the compression forces are students' milieus as graduate students (personal, academic and professional), and the tension forces are the theory and practice perspectives of journalism. But the bridge, overall, tries to balance itself — and eventually, remain sturdy_ given the compression and tension forces. In the same vein, graduate journalism education bridges the personal, academic and professional milieus of graduate students and their dealings with the usual theory-and-practice tensions in journalism.

Thus, the articulations of the respondent-graduate students can be summed up into an outcomes space which the researcher calls a Bridge of Traits of Graduate Journalism Education (Figure 2). This Bridge of Traits carries five major 


\section{Figure 2: Bridge of Traits of graduate journalism education}

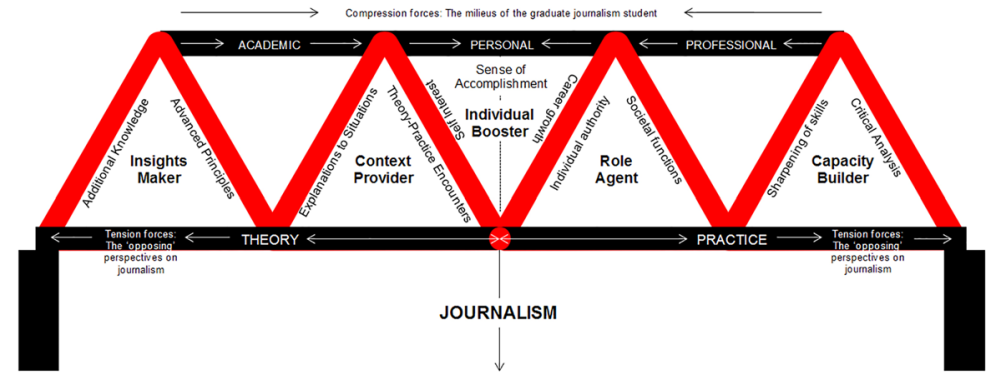

themes: 1) Insights maker (IM); 2) Context provider (CP); 3) Role agent (RA); 4) Capacity builder (CB); and 5) Individual booster (IB).

\section{Insights maker: Graduate journalism education's intuitive nature}

Respondents viewed graduate study as a provider of additional knowledge. This not only covers beginning knowledge for first-timers but also advanced knowledge. Beginners' responses reveal their interests:

I am interested about the methods: how to research, how to conduct the interview. I am also taking social psychology classes, so I want to know the methods, how to see this society, how to see this world, how to see this problem. (SP)

Anybody can write. But if you have a background in journalism, you have a guide. You are guided because you have books with instructions to follow, as well as methods and rules that you should employ and follow. Since I have no background in journalism, this is very new to me. It's like, if you want this field, you'll follow it. (AC)

Graduate journalism education also informs students of advanced principles on journalism. That was what one respondent from Ateneo realised:

There are some things that I can't learn as a print reporter producing two stories a day (your bread and butter). How much can you really learn a specific industry? But it is the same people who don't read other publications, like Financial Times. You will even learn from the way The New York Times is doing their reports. You will see your limitations: Why can't I write like them? Why can they do those things?

So it's boastfulness, for me, that others think journalists do not need to pursue graduate studies. You will see that in your first few days of reporting, and in the way they approach their work. Especially in terms of ethics: They don't understand conflict of interest. If you don't have that classroom training, or nobody tells you, you will not mind those kinds of issues. (MT) 


\section{Context provider: Graduate journalism education's explanatory nature}

Journalism in general elucidates contexts to stories that were reported. In the same boat, respondents think graduate journalism education carries an explanatory nature. Prior to understanding the situations journalists face, graduate journalism education reminded one respondent of the duty journalists have for the public: 'I think (journalists) explain the difficult things in simple ways. It's a very important role' (SP).

Having said the above, graduate journalism education explains the situations journalists face. Such explanations were what one respondent, a veteran journalist, sought for:

I think graduate study is a big help so that you get re-oriented, especially when you have long been in the industry and you are always plunged into work. You can see changes in the media industry but these are not explained to you. I think when you go back to school and take a master's degree, you are being refreshed, re-oriented and it grounds you about our profession... There are many changes in the industry that, through some courses, you can understand better how to face these changes. (LL)

Respondents think graduate journalism education also contextualises the encounters between theory and practice. On this score, some respondents acknowledge the following surrounding these encounters:

1. Theory is a pre-requisite to practice ('...When I came to Waseda, I realised the important things in journalism are the theories' [AW]; 'Once you are working, you do not have the time to learn about the theory. But it is important to have both theory and practice before going out to the real world' [MY]);

2. Theory is a guide for journalism practice ('I have a better knowledge of how politics works in Japan, so when I write about the accident in Fukushima, I get to understand what happened behind the scenes, how politics was involved in the accident, things like that. So knowledge of political science has helped (me) in (my) journalism' [MY]); and

3. Theory is thought of as a subconscious mindset in the performance of one's journalistic duties ('I think theory is helpful. There is a practical class here and we are required to report-and sometimes theory helps me on what should I do, what should I ask, and what part of the information should I take' [RY]).

\section{Role agent: Graduate journalism education's designatory nature}

Respondents do acknowledge the roles journalists play. The roles that graduate journalism education had told unto students cover individual journalists (individual authority) and journalism as a whole (societal functions). 
Beginners especially marvel at these roles ascribed unto journalists:

I think studying journalism is like, you can connect to the newest digital things and you can use social media to express your opinions and influence people. I want to connect to people and express my opinion very smoothly. (KT)

I have to tell the information, the most important things. We need to try to find things that many people don't know. Only a journalist can do that. (RA)

The students also acknowledged the societal influence journalists provide. Even if students come from countries with diverse media systems (from restrictive to being free), the respondents' recognition of the societal roles of journalism is leaned towards being the Fourth Estate:

Journalism is a watchdog for the people... to change society. Journalists report to citizens and to the origins of the information-editing the information. (TK)

For me, my first impression of journalism is criticism. Journalists have deep introspection of this world, about this society. (TC)

...the MA program we are taking in Ateneo grounds you more theoretically: What is our role in society? What is journalism?... When you are doing your job, it reminds you why you were there. You are the touch point between the people and the people with power. (MT)

\section{Capacity builder: Graduate journalism education's developmental nature}

Two sub-themes under this role emerged from respondents' answers: graduate journalism education sharpens students 'journalistic skills and develops a sense of critical analysis unto them.

As graduate-level journalism study still tackles reporting, writing and editing skills, the graduate program helped students refine these same skills - especially geared, says two respondents, to senior and supervisory roles in news organisations (MT and LL). For the new entrants, they learn new skills but with some value-added given that students are at the graduate level. There is even a 'mature' skills set that some respondents claimed to have learned from graduate school. As some of them articulated:

The Ateneo curriculum has that political aspect to journalism. So I think I can sharpen my skills there [I'm proficient in business]. If work in a different job, with different bosses or beat... I want be able to do it properly. In a way that makes my stories more informative and better for the readers. I want to add more substance in the story, to make people care about it. (MT)

I know everyone can write, everyone can just talk to people. But you... talk to people and write articles in a mature way, (telling) a mature citizen. It 
[no graduate schooling] did not help to journalism, or to improve the quality of journalism. (AC)

But much had been said on the critical analysis skills that graduate journalism education imparts. It is in this respect where theory and practice complement, that which respondents acknowledged. This theory-practice complementation differs from the earlier sub-theme on theory-practice encounters, in the sense that critical analysis is applied in the synergy of theory and practice.

1. One thing some respondents said is that the graduate program provides theoretical grounding into journalistic practice. This grounding was 'expected' in graduate study, says other respondents:

I realise that it (journalism) is not easy and you need to know the theory behind it, as well as the practical side. So yeah, you definitely need both theory and practice. (MG)

I expected theoretical and practical practice [sic] in journalism... we are now (taking an internship) for a newspaper company and so I think we needed theory. (RY)

2. Another insight from some respondents is the need to operationalise both theory and practice in conducting journalism:

I think balance is very important for me because... journalists are the experts in this field so they can have deep conversations with sources. So I think the theories are important. But the practical (things) are also important because you have to know how to ask questions, how to take photos and interviews. You will look so stupid if you don't know basic knowledge in this field and just interview the expert. (SP)

I think before learning to practice, we should learn something about the theories because we could damage (someone's reputation). Students need to know also the practical tips. But my internship mentor said I should know how to interview, take photos. So he said it is very important to learn something, to learn the theories. (TC)

3. The graduate programme provides a third theory-and-practice perspective in which critical analysis is applied: journalistic practice has its theoretical lenses. As verbalised by a Waseda student:

If you want to be a journalist, you need to understand the society that you live in. And in order to understand the society you live in, you need to understand the theory that goes with it. Like in a democratic system, how does voting work? How do people respond to journalism and the process that goes with that? So if you don't understand that, I don't think you can create news that is relevant. I think theory kind of helps journalists understand that... understand their own society better. (MG) 
4. Finally, the critical analysis lessons learned from graduate studies have made some respondents realise that theoretical discussions are a necessity in real-world journalism:

I realised why we need theory; as a reader as well of news, like we not only report but we read the news as well right? We need to know the theory in order to be critical to (an) article... Like did (the article) use this process? Is that like, credible? You can't ask these questions if you don't know the theory of journalism. (MG)

If the only training you get is on-the-job training, you won't be able to look at yourself objectively through the lens of theory. This is because you are colored with the company's style and system, you know what I mean? So if you know your theory beforehand, you can have a more critical way of thinking when you look at yourself and other journalists. (IA)

Not surprisingly, theories do clash with daily journalistic practice and mixing theory and practice 'is crazy' (LL). Nevertheless, theories have also made respondents reflect on and analyse things:

In the future, before we write something, (theory) also helps us in being responsible; there are theories we can get back from, especially the basic ones to help us know what we should write before we share these to the public. Let's face it: we don't have much time while at work. You will be lucky if someone will explain to you why these things happen right now and why the industry is currently this way. If you take (an) MA, these things will be properly explained to you. (LL)

The theory about journalism taught me to show respect to the power of journalism. Many have taught me that journalism is a very powerful thing.... and you have to use that power. (SP)

\section{Individual booster: Graduate journalism education's goal-oriented nature}

Notwithstanding the tensions between theory and practice in journalism that frequent graduate students' personal, professional and academic lives, the earlier responses show graduate education tries to balance things out. This is especially in consideration of respondents' individual goals, which graduate journalism education helps boost. Graduate studies in journalism adhere to respondents' self-interest in journalism, their aspirations for career growth, and their pursuit of a sense of accomplishment.

Varied reasons surround some respondents' self-interest into taking the graduate programme. Some found that interest through reading (MG); some linked their interest in journalism with technology (AW); others got the epiphany that journalism is a 'long-term career' (VL). For another respondent, journalism through graduate studies is an ambition: 
My ambition is to write, and to have authority, and be credible to people. I think it's also an individual aspiration; if you have the inclination of writing, and you want to make your best on it, you should go to school specialising in it. (AC)

Graduate studies in journalism are also viewed as a jump to the next phase of students' professional lives. One wants to teach (LL) while another recognises that a master's degree may be a plus should he be assigned a higher role in the news organisation (MT).

Another respondent even realised that since journalism is not her undergraduate training, and actual jobs in the industry are limited, the graduate degree is a must: 'I tried to find a job in the media. But in Japan it is very difficult to find jobs in newspaper companies because it is a small industry. So I then decided to go for the master's degree.' (RA)

The training from graduate education will even be an upgrade of the skills of the journalism student, which two graduate students recognised:

So I thought if I'm going to advance in my career. I should be able to offer potential employer, something more than just being a good reporter or whatever. And also we are moving into digital (journalism). So if I have more skills before that transition takes place, or as that transition is taking place, as I think it is now, I'm able to equip myself with better reporting tools - mostly for career advancement. (MT).

Taking a master's degree is a self-upgrade. If you learn more about the media industry, it will put you in a higher plane. You stand taller, especially now that anyone can practically be a journalist. (LL)

And if self-interest and career growth are being buoyed, the graduate journalism programme helps students develop that sense of accomplishment. The degree programme helps in students' aspirations for the following:

- Authenticity ('A master's degree [in journalism] is a form of representation for yourself. If you have that degree, you are representing yourself also' $[\mathrm{BD}])$;

- Credibility ('Career-wise I think I'd become a better journalist, like I'd not commit errors, especially related to ethics... And I can stand by what I report...to the public' [VL]); and

- Fulfilment ('If I have finished this degree and write the book I want to write, I am already fulfilled. Whoever reads it, the reader will find out its worth. Writing that book helps add to your knowledge as well as improves your character' $[\mathrm{AC}]$ ).

Even one student said finishing the graduate journalism degree programme is a 'stage of life': 
Studying a master's degree in journalism 'is a requirement for me-if you want to write with authority, credibility and inspiration. Writing has no age limit. Journalism is an art, isn't it? And it has no age limit. As long as you can write, as long as your brain is functioning, nobody can stop you. That's why I am here (in journalism master's programme)... This master's degree is important for me, because this is another chapter of my life, and maybe... the last chapter of my life. I want to finish this, that's my ambition for now.' (AC)

With regard to the relevance of graduate journalism education, one respondent averred that simply being trained on the basic skill of reporting and writing may not be enough. Graduate journalism education then comes into the picture as an ego booster:

\begin{abstract}
Some people think there is no need for... journalism education. But it builds confidence. It is a really good time to build confidence; when you know that you have more knowledge, you have more courage to interview people or to write an article. So it's (journalism graduate programme) really a good place to nurture your confidence. (MG)
\end{abstract}

\title{
Discussion
}

This study enumerated Japanese and Filipino graduate journalism students' views on the roles and purposes of taking a journalism master's degree programme. This, as respondents have recognised the 'tensions' surrounding theory and practice in journalism. The respondents' answers brought forth a 'bridge of traits' on how graduate journalism education helps these students, be it beginning or mid-career journalists. The use of a bridge to illustrate respondents' answers phenomenologically (i.e., the outcomes space) respects students' overall disposition: Both theory and practice complement, while their graduate programme portrays the roles of insights maker, context provider, role agent, capacity builder, and individual booster.

The contribution of the Bridge of Traits of Graduate Journalism Education is that students are providing perspectives on how graduate journalism education may look. From a programmatic standpoint, respondents' answers reinforced, in more ways than one, the elements of an ideal program in journalism that Folkerts, Hamilton and Lemann outlined (2013). There can be intersections surrounding what the journalism deans wrote and what the respondents of this study answered (Table 3), as the fifth trait-individual booster-personalises the place of graduate journalism education unto the student.

Observations on graduate journalism education as insights maker and capacitybuilder affirm Saalberg's findings (1970) that non-journalism bachelor's degree holders find value from the skills they learned in graduate journalism education. While many of this study's respondents do not hold journalism bachelor's degrees, these students do understand the demands of journalism practice and analysis at both beginner and advanced levels. And since the degree is a graduate degree, these respondents can 


\begin{tabular}{|l|l|}
\hline \multicolumn{2}{|c|}{ Table 3: Intersections of the elements and traits } \\
\hline Bridge of traits & Elements of graduate journalism education \\
\hline Context provider & $\begin{array}{l}\text { Guided practice, historical knowledge, methods of analysis, } \\
\text { theory }\end{array}$ \\
\hline Insights maker & Guided practice, evolution and adaptability \\
\hline Role agent & $\begin{array}{l}\text { Guided practice, evolution and adaptability, diversity, media } \\
\text { law and ethics }\end{array}$ \\
\hline Capacity builder & Guided practice, theory, diversity, media law and ethics \\
\hline
\end{tabular}

Adapted from: Folkerts, Hamilton and Lemann, 2013

become 'more solidly grounded' in journalism and media (Saalberg,1970).

Respondents' answers on the role agent trait only confirm that the roles of journalism and of journalists are a commonplace discussion in journalism education. It is but inevitable for respondents to share their feelings about the roles journalists play. Journalists' roles were also questioned by Schultz (2002) and O'Boyle and Knowlton (2015). Interestingly, some respondents' answers reveal the influence of their home countries' news media systems. Some answers even affirm a desire by respondents to feel the Fourth Estate disposition of journalism, at least through graduate studies.

The context provider trait is interesting. This set of answers came about as a result of the usual training that journalism provides: that stories on events and issues be contextualised. It is under this trait that the theory-and-practice discussion continues. Respondents were candid in their young views surrounding this debate, given the context that journalism is intrinsically a practice-oriented field.

Respondents may have understood theory as things that do not only make sense of what is happening around them. 'Theory' or 'theories' is/are those that have been taught in school, like definitions, principles, concepts or the theories themselves. What adds up here is the setting, the journalism school in a university set up: the learning of graduate-level journalism is now beyond the skills being taught, but is traversing critical analysis of the writings and actions of journalists, and the interactions between journalism and other stakeholders in the society the journalists cover (also in Chapman \& Papatheodorou, 2004). This can be gleaned from verbalisations such as undergraduate training in political science that can be used in reporting and writing (MY), or even the news media system and political milieu that influence journalists' work (MG).

Scholars have engaged in somewhat heated intellectual arguments about how theory and practice collide in journalism and journalism education (Barkho, 2013; Bacon, 2011; Greenberg, 2007; Robie, 2014, 2015). But the responses of these graduate students reveal their simplistic — but meaningful — understandings of how theory and practice complement. Considering theories as pre-requisites (AW, MY), guides (MY), subconscious mindsets (RY) and even necessities (MG, 
IA) is a modest leap of faith from how scholars abhor either theory or practice, or try to bridge these two worlds but are having a hard time. If such answers came about, the three graduate journalism schools and their courses may have been successful in balancing theory and practice, with journalists learning two categories of knowledge: academic and professional (de Burgh, 2003)

Except for two respondents who have more than five years of journalism experience (reporting, editing), the rest of the respondents are newcomers to the field. This length of experience influences how the Theory of Reflective Practice of Schön and the Reflective Cycle of Gibbs are being applied. A future study, of seasoned journalists who are also graduate journalism students, can see how these theories make journalists exercise critical self-reflection (Chapman \& Papatheodorou, 2004). But for now, some verbalisations by respondents show efforts by these graduate students to reflect on the work of journalists, on trends in the profession, on the implications of journalists' articles and roles, and on journalism's place in a society. Graduate journalism school even answers queries on trends in the profession that a respondent's daily immersion in the news media industry cannot, or may not have the time to, answer (LL). This shows that graduate journalism education is a reflective place for him to understand further the news media industry.

Sure, some theories do not apply in real-world journalism. Given also that the majority of respondents are newcomers, their verbalisations may have lacked the insight of how practice can also influence theory (Chapman \& Papatheodorou, 2004). But graduate journalism school became a watering hole to ponder on their own skills and on the issues facing journalists and their practice (or even the journalism sector in their own countries).

In the formality of graduate journalism education under a university setting, the individual booster trait provides a personalised feel into the discussion. Not surprisingly, graduate journalism education for some of these respondents is a ticket to career advancement and improved self-confidence. But for some respondents to say that graduate journalism education provides a stamp of authority (AC) and legitimacy (BD) even to the newcomer will be an endearing statement on the part of the journalism programme head.

The researcher recognises the limitations of having only 16 respondents for this phenomenological study. Having more respondents, especially practising journalists, may have provided further insights. Nevertheless, the Bridge of Traits on Graduate Journalism Education is a humble contribution this paper brings forth to the study of journalism education worldwide.

\section{Conclusion}

There is a dearth of literature on the roles and purposes of taking up graduate education in a field - journalism - that is highly associated with its practice. This phenomenological study thus attempted to find out why these beginning and 
seasoned journalists from Japan and the Philippines take up graduate studies, and what is the goal of such level of journalism education unto them. Answers from 16 Japanese and Filipino graduate journalism students yielded the Bridge of Traits of Graduate Journalism Education that illustrates these roles and purposes of graduate studies. This bridge of traits also entered into the theory-and-practice discussions that have frequently divided scholars, educators and professionals in the journalism field.

Reflective practice in education and learning was evident in some answers by respondents. Their answers may be based on a simple understanding of the things they have learned in the graduate school, or experiences acquired from doing daily journalism work that were brought inside the classroom. But students recognised the possibilities and tensions of blending theory and practice in the field of journalism.

Thus saying, this Bridge of Traits of Graduate Journalism Education represents respondents' efforts to connect their personal, academic and professional milieus and aspirations as journalists. Making these connections is done within the realm of journalism's theory-practice continuum which, as respondents surprisingly articulated, is important, complementary and applicable. Such articulations provide hope to visions of graduate journalism education, within or outside a university: A viable graduate journalism program implements several elements in pedagogy and substance (Folkerts, Hamilton \& Lemann, 2013) that espouse a spirit of critical reflective practice unto journalists (Greenberg, 2007; Chapman $\&$ Papatheorodou, 2004) and that aspire for new perspectives and approaches to the teaching, study and practice of journalism.

This research was done aiming at moderatum generalisation, and further refining the Bridge of Traits of Graduate Journalism Education will be helpful. Nevertheless, respondents' verbalizations are indicative and can lead to further studies on other aspects of graduate journalism education: programme delivery, outcomes achieved, the influence of graduate studies unto daily journalism practice, how theories may improve journalism practice, and how trends from journalism practice may advance journalism knowledge and theories.

It is recommended that the three journalism schools determine ways how a reflective education (de Burgh, 2003) will enhance graduate program delivery. For now, reflective practice is a workable approach to bridge the theory-practice divide (Greenberg, 2008). Reflective practice can even open up dialogues between professionals, scholars and teachers/educators (Zelizer, 2004), leading to a more integrated set of views on journalism as a profession and as a discipline. Reflective education can hopefully lead to producing master's degree-bearing journalists who can improve either daily journalism practice or journalism knowledge-generation, or both. This can be a curricular agenda for journalism schools worldwide with graduate programs.

But seeing the graduate student achieve personal fulfillment from completing 
this master's degree is, for the meantime, a source of triumph for the journalism school. What these journalism schools hope next is that their products make a difference in the field of journalism.

\section{Notes}

1. In an earlier piece, Adam (1989) affirmed an earlier statement of Joseph Pulitzer: journalism is a literary craft in itself, so literature must be taught in the courses.

2. Graduate education for journalism includes taking a $\mathrm{PhD}$ in journalism and related fields, with doctoral education preparing graduates to conduct research (Christ \& Broyles, 2007). However, doctoral studies as a form of graduate or postgraduate education are not included in this article. Christ and Broyles' paper included master's and doctoral students as respondents.

3. The Filipino students of ACFJ were emailed several times requesting an interview at places and times of their convenience. They did not reply to the researcher's repeated email requests, even to backdoor requests made through classmates who were eventually interviewed.

\section{References}

Adam, G. S. (1989). Journalism knowledge and journalism practice: The problems of curriculum and research in university schools of journalism. Canadian Journal of Communication 14(2), 70-79.

Alagaran, J.R. II, Portus, L., \& Tuazon, R. (2012). Communication as a field of study in the Philippines. In Miralao, V. \& Agbisit, J. (Eds.), Philippine Social Sciences: Capacities, Directions and Challenges (pp. 127-140). Quezon City, Philippines: Philippine Social Science Council.

Anuar, M. (2015). Journalistic outputs and academic expectations. Asia Pacific Media Educator, 25(1), 87-91.

Bacon, W. (2011). Engaging theory and practice in journalism education. Asia Pacific Media Educator, 21, 24-42,

Banerjee, I. (2009). Asian media studies: The struggle for international legitimacy. In Thussu, D. K. (Ed.), Internationalizing Media Studies (pp. 165-175). Abingdon, Oxon., United Kingdom: Routledge.

Banerjee, I., \& Logan, S. (2008). Asian communication handbook 2008. Singapore: Asian Media Information and Communication Centre.

Barkho, L. (2013). Media academics versus media practitioners: Who gets it right? Journal of Applied Journalism and Media Studies, 2(3), 377-286.

Bromley, M., Tumber, H. and Zelizer, B. (2001). Journalism Education. Journalism: Theory Practice and Criticism, 2(3), 251-4.

Carey, J. (1978). AEJ Presidential Address: A plea for the university tradition. Journalism Quarterly, 55, 846-855. Retrieved from: http://www.aejmc.org/home/wp-content/ uploads/2012/09/Journalism-Quarterly-1978-Carey-846-55.pdf

Carpenter, S. (2008). A study of graduate student authorship in journalism and mass communication journals: 1997-2006. Journalism and Mass Communication Educator, 63: 224-240.

Chapman, J., \& Papatheodorou, F. (2004). The place of critical self reflection in journalism 
education: An inquiry into student responses to the theoretical and practical components of the undergraduate curriculum. In Davies, A. (Ed.), Enhancing curricula: Towards the scholarship of teaching in art, design and communication in higher education. London, UK: Centre for Learning and Teaching in Art and Design, University of the Arts.

Christ, W. G. and Broyles, S. (2007). Graduate education at AEJMC schools: A benchmark study. Journalism and Mass Communication Educator, 62(4), 376-401.

Chua, Y. (2015). Investigative journalism as academic output? That will be the day. Asia Pacific Media Educator, 25(1), 13-20.

Clarke, J. (2010). Journalism education and the reality of journalism practice. Asia Pacific Media Educator, 20: 225-229.

Colaizzi, P. F. (1978). Psychological research as the phenomenologist views it. In Valle, R. and King, M. (Eds.), Existential phenomenological alternatives for psychology (pp. 48-71). New York, NY: Oxford University Press.

De Burgh, H. (2003). Skills are not enough: The case for journalism as an academic discipline. Journalism, 4(1), 95-112.

Duffy, A. (2015). Journalism and academic writing: Sibling rivalry or kissing cousins? Asia Pacific Media Educator, 25(1), 5-12.

Finlay, L. (2008). Reflecting on reflective practice. PBPL Paper 52, Practice-Based Professional Learning Center, The Open University (United Kingdom).

Folkerts, J. (2014). History of journalism education. Journalism and Communication Monographs, 16(4), 227-299.

Folkerts, J., Hamilton, J.M., \& Lemann, N. (2013). Educating journalists: A new plea for the university tradition. New York, NY: Columbia Journalism School, Columbia University.

Franklin, B. \& Mensing, D. (eds.) Journalism education, training and employment. New York, NY: Taylor \& Francis.

Greenberg, S. (2007). Theory and practice in journalism education. Journal of Media Practice, 8(3), 289-303.

Hanna, M., \& Sanders, K. (2007). Did graduate journalism education make a difference? A study of British journalism students' views on news media roles. Journalism and Mass Communication Educator, 62(4), 344-359.

Humanes, M. L., \& Roses, S. (2014). College students' views about the journalism education in Spain. (Valoracion de los Estudiantes sobre la Enseñanza del Periodismo en España). Communicar Media Education Research Journal. doi: 10.3916/C42-2014-18.

Josephi, B. (2015). Journalism education. Communication: Oxford Research Encyclopedias. doi: 10.1093/acrefore/9780190228613.013.92

Josephi, B. (2007). Internationalizing the journalistic professional model: Imperatives and impediments. Global Media and Communication, 3(3), 300-306.

Kemper, K. (2015). Journalism as academic research: Just give them what they want! Asia Pacific Media Educator, 25(1), 74-81.

Kolb, D. (1984). Experiential learning: Experience as the source of learning and development. New Jersey, NJ: Englewood Cliffs, Prentice-Hall.

Lahav, H. (2008). If you can't earn enough — teach. Newspaper journalists as journalism lecturers in Israel. Journalism Practice, 2(3), 463-475.

Larsson, J., \& Holmström, I. (2009). Phenomenographic or phenomenological analysis: Does it matter? Examples from a study on anaesthesiologists' work. International Journal on Qualitative Studies on Health and Well-Being, 2(1): 55-64. doi: http:// dx.doi.org/10.1080/17482620601068105

Lemann, N. (2009). Journalism schools can push coverage beyond breaking news. The Chronicle Review, November 20: B8-B9. 
Lia, P. (n.d.). Learning support tutor: Disability advisory service. Retrieved from https:// www.kcl.ac.uk/campuslife/services/disability/service/Using-Gibbs-Reflective-Cyclein-Coursework.pdf

Lincoln, Y., \& Guba, E. (1985). Naturalistic inquiry. Beverly Hills, California, CA: Sage Publications.

Lugo-Ocando, J. (2015). Journalists do live in a parallel universe: A response to practitioner critiques of journalism academics. Journal of Applied Journalism and Media Studies, 4(3), 369-280.

Marron, M. (2014). Graduate degrees in journalism and the MBA. Journalism and Mass Communication Educator, 69(1), 3-4.

Marsh, K. (2015). Journalism practitioners and the academy: Must they eternally live in different universes? Journal of Applied Journalism and Media Studies, 4(2), 195-204.

Mason, D. (2015). Accept journalistic work as 'output' to keep the professional 'street cred' in teaching journalism. Asia Pacific Media Educator, 25(1) 21-27.

Mensing, D. (2011). Realigning journalism education. In Franklin, B. \& Mensing, D. (eds.) Journalism education, training and employment (pp. 15-32). New York, NY: Taylor \& Francis.

Murphy, S., \& Scotton, J. (1987). Dependency and journalism education in Africa: Are there alternative models. Africa Media Review, 1(3), 11-35.

Murthy, C.S.H.N. (2015). Journalism cannot both be 'subject and research' per se. Asia Pacific Media Educator, 25(1), 92-97.

O’Boyle, N., \& Knowlton, S. (2015). Coming to journalism: A comparative case study of postgraduate students in Dublin and Amman. Journalism and Mass Communication Educator, 70(4), 382-393. doi: 10.1177/1077695815598612.

Ray, V. (2014). Journalists and scholars: A short manifesto. Journal of Applied Journalism and Media Studies 3(2), 125-132.

Reese, S. (1999). The progressive potential of journalism education: Recasting the academic versus professional debate. The International Journal of Press/Politics 4(4), 70-94.

Remler, D., Waisanen, D., \& Gabor, A. (2013). Academic journalism. Journalism Studies 15(4): 357-373. DOI: http://dx.doi.org/10.1080/1461670X.2013.821321.

Robie, D. (2014). Don't spoil my beautiful face: Media, mayhem and human rights in the Pacific. Auckland, NZ: Little Island Press.

Robie, D. (2015). Advocating journalism practice-as-research: A case for recognition in the New Zealand PBRF context. Asia Pacific Media Educator, 25(1), 62-73. DOI $10.1177 / 1326365 \times 15575591$

Saalberg, H. (1970). Graduate students welcome opportunities to learn J-fundamentals they lack. Journalism and Mass Communication Educator, 25(2), 22-25.

Schön, D. (1983). The reflective practitioner: How professionals think in action. New York, NY: Basic Books.

Schudson, M., \& Downie, L. Jr. (2009). University-based reporting could keep journalism alive. The Chronicle Review, November 20: B6-B7.

Schultz, T. (2002). Does education matter? Characteristics of journalists who went to graduate school. Journalism: Theory, practice and criticism, 3(2), 223-238.

Self, C. (2015). Global journalism education: A missed opportunity for media development? CIMA Insights. Retrieved from www.cima.ned.org/wp-content/uploads/2015/06/CIMA-Global-Journalism-Education.pdf.

Shafer, R., \& Freedman, E. (2015). Adapting the western journalism education model for application to press systems in central Asia: Reflections on Uzbekistan and Kyrgyzstan. Paper presented at the 2015 International Association for Media and Communication 
Research (IAMCR), Montreal, Canada.

Soloski, J. (1994). On defining the nature of graduate education. Journalism and Mass Communication Educator, 49(2), 4-11.

Takeichi, H. (1996). Journalism education in Japan: Its present state and problems. Departmental Bulletin Paper, Sophia University Department of Journalism. http://repository. cc.sophia.ac.jp/dspace/bitstream/123456789/17688/2/200000016987_000070000_21.pdf

Tanner, S. (2015). Journalism can establish its credentials - all it takes is a little research. Asia Pacific Media Educator, 25(1), 41-47.

Tata Steel Corporation. (n.d.) 'Truss bridges.' Retrieved from www.tatasteelconstruction.com/ en/reference/teaching-resources/steel-bridge-resources/21st-century-bridges/truss-bridge.

Thorson, E. (2005). Reconceptualizing the influence of the news industry on journalism graduate education. Journalism and Mass Communication Educator, 60(1), 17-22.

Terzis, G. (2009). European journalism education. Bristol, UK: Intellect Ltd.

UNESCO Secretariat. (1961). Professional training of journalists in China, India, Indonesia, Japan, Korea, Pakistan, Philippines and Thailand. Presented at the Seminar on Journalism Training Methods in South and East Asia. http://unesdoc.unesco.org/ images/0014/001473/147390eb.pdf

Wanta, W. (2003). Preparing graduate students to teach: Obligation and practice. Journalism and Mass Communication Educator, 58(3), 209-238.

Webb, A. (2015). How to make J-school matter (again): A blueprint for the future of journalism education. Cambridge, MS: Nieman Foundation for Journalism, Harvard University.

Wojnar, D., \& Swanson, K. (2007). Phenomenology: An exploration. Journal of Holistic Nursing, 25(3), 172-180.

Woolley, B. (2015). Recognizing the limitations of journalism as academic research while arguing for change. Asia Pacific Media Educator, 25(1), 33-40.

Zachary, G. P. (2009). Embedding journalists in the academe. The Chronicle Review, November 20: B10-B11.

Zelizer, B. (2004). Taking journalism seriously: News and the academy. Los Angeles, CA: Sage. University of Pennsylvania.

The author wishes to acknowledge financial support for this research and authorship of this article with a grant of US\$5,000 (grant number: 138513) from the Sumitomo Foundation of Japan under its annual research grants program. The University of Santo Tomas' Research Center for Culture, Education and Social Issues (RCCESI) also provided logistical support. Research assistance from journalism students Jan Carlo Anolin and Minka Klaudia Tiangco, and from research professional Andrew Lacsina, is also acknowledged.

Jeremaiah Opiniano is assistant professor in the journalism programme of the University of Santo Tomas (UST) in Manila, Philippines. He is also publisher of a community news organisation, The Filipino Connection (www.thefilipinoconnection.net). An earlier version of this paper was presented at the World Journalism Education Congress (WJEC) 2017 conference in Auckland, New Zealand, July 2016. jmopiniano@ust.edu.ph 